\title{
Legal Protection for the Poor in order to get Fair Health Services
}

\author{
Takdir, SH., MH. \\ STAIN Palopo, South Sulawesi - Indonesia
}

\begin{abstract}
This research discusses about the law of health services in order to guarantee the legal protection for the poor in order to access their right of fair health. The method of research is used the normative- empirical research while focusing to analysis the Law and norms under positive law by analytical approach and statute approach. This research found that there is still found some discrimination treatment between the have and the poor, like there is a limitation of health facility on third class that provided for the poor based on the minimal standard of health, so on with the limitation to the used of drugs based on local governor Number 13 year 2008. The allocated of financial support to the health service did not balanced while the government only take $40 \%$ and local government take $60 \%$ of free budget of services health.
\end{abstract}

Keywords: Legal Protection, Health Service, the Right, Indonesia

\section{Introduction}

1.1 Background of Problem

Health is a basic need for everyone due to the healthy condition of human being that able to do activity in fulfills the daily living need. To get the good health, everyone will sacrifice everything they have in order free from disease. Health is everything even compare with money.

Based on World Health Organization (WHO) that have been ratified by the government under Law number 23 year 1992 of Health that have been revised by the government to the Law number 36 year 2009 of Health and The RI Constitution 1945 article $28 \mathrm{H}$, maintain that health is fundamental right for everyone due to each of individual, family and society have right to get the protection of their health, and The State has responsible to arrange in order the fulfillment of the poor .(Depkes RI, 2009). Apart from that, article 34 the RI Constitution of 1945 Fourth amendment managed the State responsibility to the poor and facility provided to the access of adequate.

People in order to get the health service is should get the adequate quality service based on medical indication, nor to get the service health based on the financial ability.

Along with the free health program that organized by the government is not even increase the welfare of people, especially in access the medical service, it can be seen from the lack of health of the people, due to the difficulties of access to the medical service that provided by the government, like un well recorded the receiver of jamkesmas (guarantee of society health). There are still affordable persons that used this facility as well.

The low of health is affected to the low of work productivity which is become to the burden to government and society. The fulfillment of medical service is need more attention in the decentralization era, due to not all the region affords to health finance care. The positive perception from stakeholder will support the service health program for poor people in South Sulawesi.

It is become a challenge for the government to seen the lack of health service for the poor compare to the affordable people, whether the service health in keeping the health and the service health to cure disease. Often that the poor should have free access to the health care but in fact its not free at all, due the still pay for the medicine that prescribed by the doctor while is not free, a lot people that afford economically have taken away the right of poor people to enjoy the facility of free health that should be for the poor, The unfriendly treatment from the nurses since they thought that poor is borne by the government. Also there is a limited of kind of service of health that unable to receive by the poor refer to the government Law number 13 year 2008.

1.2 Problem Analysis

According to the background above, so the problem analysis that should be discussed it about: how is the better form regulation of health services in guarantee the legal protection for the poor in the right of equitable health service?

\section{Literature Study}

\subsection{Legal Protection to the State Law}

2.1.1 State Law

According to F.R.Bothlingk in Oostenbrink et.al. (2003), state law is "de staat, waarin de wilsvrijheid van gezagsdragers is beperkt door grenzen van recht" (Freedom of willingness to the power held is limited by the Law). A. Hamid S. Attamimi, by quoted the Burknes, stated that State Law (rechtsstaat) simple is state put law as basic power of the state and run everything under the power of law. In State Law, everything must be done according to law. State Law maintained that the government should respect to the law. 
State Law Concept mentioned by F.J. Stahl in Budiardjo (1982) is welfare state or Welvaarstaat (Dutch), Social Service State (English), while there are same element of the State Law (rechtsstaat)as following:

1. Protection Of Human Right

2. Separate or divide power to guarantee the right of citizen.

3. Government according to Law

4. There is a Administration Court

According to the Constitution RI of 1945 (before the amendment), There are some elements of the State Law, like,first, principle of people dignity (article 1 point 2), second, Government according to the constitution Explanation of constitution RI 1945), Third, Guarantee to the Human Rights (article 27, 28, 29, 31), Fourth, Divide the Power (article 2, 4, 16, 19), Fifth , Monitoring the Court (article 24), Sixth, Citizen participation (article 28), Seventh, Economic System (article 33).

2.1.2. Legal Protection

The word of protection defined as a place of protection, in order to act and other. From both of definition, contain 2 (two) important meaning like: a. Place or tools that have chosen and used to protect or following the activity, b. An person, group, state administration or government institution act in order to give the right and obligation to others trough regulation, decision and wisdom. Legal protection for citizen is an obligation and integral part since human right is maintain under the constitution as well under the Human Rights International instrument that ratified by the government under Law number 39 year 1999 of Human Rights.

Legal protection for citizen is a universal concept, which is means and implemented by each state which is called as State of Law. The Legal protection under civil Law:

As mentioned by Sudargo Gautama (1973) that:

"The Government on carrying its duty, need the freedom to act ans have the special authority compare to original people. So to claim the government in the court can be the same by claim the other citizen."

Along to the government acts that against the Law, according to J. Spier et.al. (1987) that:

"de burgerlijke rechter is-op het gebied van de onrechtmatige overheidsdaad bevoedg de overhead te veoordelen tot betaling van schadevergoeding. Daarnaast kan hij in vell gevallen de overhead verbieden of gebieden bepaalde gedragingen te verrichten. (Civil Judge to the act that against the law by the government, authorized to executed to pay some restitution. Beside that, the civil judge in other circumstances allowed issuing the forbid or order to the government in makes certain act.)

According to the explanation above, it can be concluded that when the government ignore its authority to protect the right of poor citizen to access the right of fair health, then the government could be accused.

Legal protection is based under article 53 point (2 Law number 9 year 2004 of Administration Court, which is function to control every administration act of the state and also to give the protection to the State Administration. So need the instrument of Law as indicator, like existing Law and general principle of good governance.

According to article $28 \mathrm{H}$ point (1) RI Constitution 1945, the right of health of citizen is became of the Government responsibility in order to give the legal protection to get the access of health care. The legal protection in health care like promotes protection, preventive and rehabilitative. According to article 32 Law number 36 year 2009 of health, in emergency case, hospital both private and government forbidden to reject the patient and / or request deposit for the service health.

2.2 Concept of Justice

Justice is a rights condition according to morality about the good thing, whether for people or things. According to some of theory, justices have the big interest. John Rawls, stated "Justice is first virtue from social institution, as the truth on the mind system ".

John Rawls under his book a theory of justice describe the social justice theory as the difference principle and the principle of fair equality of opportunity. The main of the difference principle, is that the distinguish of social and economic must be arranged so the biggest used for them whom un lucky. The word of distinguish of social - economic in differentiate principle to the differentiation on people prospect to get welfare, income and authority. While the principles of fair equality of opportunity have shown that they need to have a special protection.

2.3 Legal Based of the Local Government

In the earlier of the established of Republic Indonesia, 17 August 1945 with decentralization system, the founder of state have stipulated choice to the separate power principles in running the Government with the clear purpose as mentioned on paragraph fourth of the preamble of Constitution RI 1945,

“... To protect the whole country of Indonesia and the whole people and to increase the public welfare, educated the people in and participating in keep peace in the world based on freedom, peaceful and 
social justice ".

\subsection{Public and Health Service}

\subsubsection{Public Service}

Public service can be defined to serve the demand of people or community whom have the interest on the organization that along together with the existing rule. Service is an act of government that on the essential for the interest of people.

The idea of David Osborne and Ted Gaebler of Reinventing Government mentioned under his book with the title Reinventing Government: How the Entrepreneurial Spirit is Transforming the Public Sector that published on 1992 and Banishing Bureaucracy: The Five Strategies for Reinventing Government last book that written by David Osborne and Peter Plastik that published on 1997. The idea came out as responded to the worst of public service in USA which is caused the un trust to the government.

The ideas of Osborne and Gaebler about Reinventing Government had covered 10 principles to bureaucracy, like in the following (David et.al, 1996):

First, the capitalist of Government: prefer to direct that row, means that the entrepreneurship of the government is should be concentrate to the law making strategic wisdom that busy with the technical things.

Second, government is own by the people, means more to give the authority than do the service. Bureaucracy of government is should concentrate to the service, empowerment the people, communities, social communities to be a source of solving the conflict. It can be a controlled to government works..

Third, the competitive government, that the injected the competition to the service. Means the government should develop the competition between the people and private and also the non government organization in public service sector.

Fourth, the government that moved by the mission: to change the organization by the rule. Means the running government based on rule will not be effective and less of efficient due to the slow and complicated work.

Fifth, the government that oriented to the result: maintain the result not income. Means the institutions of the government funded based to the income so will have such a less of reason in working hard to reach the good capacity of work, but when the funded based on outcome, they willing to get a achievement.

Sixth, The government oriented to the consume: to fulfillment the demanding of consume, not a bureaucracy, means, the government should place people as consuming that must be pay attention to its interest.

Seventh, means to institute the concept of profit motif in public world as example to maintain the cost for public service and the collected money will use to invest and maintain the innovations in other public service. With this activity, the government will create the addition value and guarantee the result even in difficult finance situation.

Eight, The government anticipative to prevent than to fix, Means that the pattern of preventive must be put first than to fix, remind the public problems that more complex these day..

Ninth, Decentralization government, from the hierarchy to the participant and team work. Means the cooperation between government institution, business sector and civil society sector need to keep in order maintaining the team work in public service.

Tenth is the government that oriented to the market: increase the changes to the market. Means, the government or public organization better function as facilitator to collect the capitalist..

Under the government, the definition of public service is arrangement trough the letter decision of State Minister for the Empowerment of State apparatus, Number 63 year 2003, which is the whole activities that carry on by the administrator public as the effort of fulfillment demanding of service receiver and the regulation itself.

\subsubsection{Health Service}

According to the Law Number No. 23 year 1992 of health, article 1 no. 15 that " the guarantee of health care of people is the arrange of health care based on the work together principle and family principle with the good quality together with the financial support that have carry on. ".

On the implementation, it should be preventing the things that could be bothering the achievement of health increase, like:

1. There is a limitation of the participant due to the age, high risk job and the economic social living level, etc.

2. There is a general check up to the health as the required to become a participant.

\subsection{The essential and Poverty Measurement}

According to the Law number 13 year 2011 of the handled of the Poor People, under article 1 explained that poor people is a person who can afford at all, neither have job, neither to afford their daily living life nor for himself and to his family. 
Poverty classified by the Directorate General of Agrarian is like in the following:

1. Very Poor, if the consuming per capita per year as much as $75 \%$ from total value of consume nine basic of food that have maintained;

2. Poor, if consuming per capita per year is only $75 \%-125 \%$ from total value of nine basic food consume that have maintained;

3. Almost Poor, if consuming per capita per year as much $125 \%-200 \%$ from the total value of nine basic foods that have maintained.

\section{Research Method}

\subsection{Research Design}

This study employed the descriptive research design which is a method that used to describe, interpret substation of guarantee of society health's law and implementation.

\subsection{Types and Sources of Data}

The study principally made use of primary and secondary data. The primary data employed included data from interview and observation. Secondary data included data on substation of main rule which is become discussion in this research such as: Constitution RI 1945, regulation No. 36 years 2009 about health, regulation No. 40 years 2004 about system of national social guarantee.

3.3 Procedure of Data Collection

Procedure of data collection is doing by documentation on regulation that related with research problem, observation which is done by observe implementation of health service, interview is done by related institutions 3.4 Method of Data Analysis

Data obtained from the research were analyzed using empiric normative analysis qualitatively

\section{Discussion and Analysis}

The development in health field must be followed by the legal development. It is connected with the relevant application as basic consideration to do the development in health field, apart from that, also according to the theory of welfare State by J.F Stahl, State must be guarantee the implementation of human rights, one of them is to guarantee the health of its people with the regulation of health, like to maintain the clear regulation in field of health in order to get the certain law on the implementation level.

To valued the regulation whether good or not, can be done by seeing the form of regulation and contain under those article also the implementation by the authority. Especially the regulation on people health can be valued as like in the following:

1. Regulation Form

The implemented of free health program as the wisdom that maintain by the government of South Sulawesi, based on three (3) regulations, like the Governor regulation of South Sulawesi number 13 year 2008 about the guidelines of implementation the free health service program in South Sulawesi, Governor regulation number 15 year 2008 of regionalization on reference hospital system in South Sulawesi and the local government of South Sulawesi number 2 year 2009 of the cooperation of administrator of the free of health service. From those 3 (three) of regulation, there is a mistake on the issued, it should be the local government first, then followed by the implementation of regulation form under the local government regulation or governor regulation.

On the considerate of the governor regulation number 13 year 2008,maintained: "The administrator of the development health, specially the free health service for people need to do continuously, integrated, synergic and holistic along with sharing cost from all the local government in South Sulawesi. Medium and infrastructure of health, human resource and the quality of service must be meet the minimum standard of service.

According to the regulation if refer to the Constitution RI 1945 amendment IV into article 28I Part (2) and (4) clearly un synchronized because the article demand there is no discriminative at all to the health service, and State responsible for the protection, promote and fulfill of the Human rights in health service that must be given maximum refer to the medical indicated. It is along together with the article 23 point (4) Law number 36 year 2009 of health, in giving the health service, not allow to put money but put the medical indicated as priority together with no discrimination.

2 Substance of The Regulation of Free Health Program

Article 2 of governor regulation number 2 year 2009 about the cooperation on performance of free health service that maintain the cooperation performance refer to the principle: $a$. Efficient, $b$. Effectiveness, c. Synergy, d. Benefit each other, e. Agreement, f. Good faith, g. Transparent, h. justice 
and , i. certain Law.

Free health service implemented based on cooperation between government of province and government of regions also third parties like institution of health and the company of health assurance with the budget source from the finance of local government cost. Budget provided on province only $40 \%$ while the regions provided around $60 \%$. Those budgetary provided under the financial plan of local government budget based on application. This is hard for some of the regions.

Apart from complaining that the budget is seem to be a matter in implementation of the free service health, also the target of the participant of free health is not exactly right. So need to have controlling system, supervision and good report.

\section{Enclosed}

\subsection{Conclusion}

Based on the explanation above, can be concluded that, basically the implementation on free health service program refer into the Constitution RI 1945 amendment IV under article 28 I part (2) and (4) that : (2) Everyone have right to be free from any discriminative treatment.(4) protection, promote and fulfill the human right, is the obligation for State, specially the government, but in practice based on the implementation regulation of the free health service, still found the discriminative treatment like limitation of the health facility provided for third level for poor people with minimum standard of service, included the medicine, the exception to the nurses that un able to give free based on governor regulation number 13 year 2008. Those treatment is not treatment based on medical indicated anymore. The implementation of regulation is not synchronized with the regulation above. Apart from that, the health service is become the obliged of the local government with the allocated budget is not balanced, while Province only took around $40 \%$ and the rest have taken by the local government around $60 \%$.

5.2 Suggestions

From that conclusion above, then need to delivered some suggestion, like:

1. It is necessary to re analysis the regulation on free health service, like governor regulation Number 13 year 2008 which is still limited the service health for the poor since the existing program of health people guarantee should be completing for the implementation of health people program that still have lack in the implementation level. Apart from that, the exist of healthy BPJS on 1 January 2014, where the budgetary of health able to use for service the medical condition that far away to reached.

2. It is should be re form of free health regulation that involve the government both province and district, health institution, third parties like Assurance Company (PT AsKES), the head of hospital or medical clinic and academician in medical field in order the implementation of health

\section{References}

\section{Text Book Literature;}

Azrul Azwar, 1996. Pengantar Administrasi Kesehatan. Binapura Aksara. Jakarta.

Abdul Aziz Hakim, 2001. Negara Hukum dan Demokrasi di Indonesia, Pustaka Pelajar, Yogyakarta.

Azhary, 1995. Negara Hukum Indonesia, Analisis Yuridis Normtif Tentang unsur-unsurnya, UI Perss. Jakarta.

Andre Ata Ujan, 2001. Keadilan dan demokrasi telaah filsafat politik john rawls. Penerbit kanisius. Yogyakarta.

Amrah Muslimin, 1986. Beberapa Asas-asas dan Pengertian-pengertian Pokok Tentang Administrasi dan Hukum Administrasi. Alumni. Bandung.

Andi Hamzah, 1986. Kamus hukum, Penerbit Ghalia Indonesia.

Adami Chazawi, 2007. Malpraktek Kedokteran (Tinjauan Norma dan Doktrin Hukum), Penerbit Bayumedia Publishing. Malang..

Ahmad Zaenal Fanani, Teori Keadilan dalam Perspektif Filsafat Hukum dan Islam, (Hakim PA Martapura; mahasiswa program doktor (S3) ilmu hukum UII Yogyakarta)

Amri Amir, 1997. Bunga Rampai Hukum Kesehatan. Widya medika. Jakarta.

Ansor. Konsep Negara hukum,(Yogykarta: Makalah S2 UII)

Bagir Manan, 1986. Peran Peraturan Perundang-undangan dalam Pembiinaan Hukum Nasional. Armico. Bandung.

Bayu Surianiingrat. 1980. Organisasi Pemerintah Wilayah Daerah. Aksara Baru. Jakarta.

David Osborne dan Ted Gaebler, 1996. Mewirausahakan Birokrasi, terj. Abdul Rasyid, : Pustaka Binaman Pressindo, Jakarta.

Djoko Wijono, 1999, Manajemen Mutu Pelayanan Kesehatan, Airlangga University Press, Surabaya.

Didi Nazmi Yunas, 1992. Konsep Negara Hukum. Padang: Angkasa Raya Padang.

Dahlan Thalib dan Mila Karmila Adi (editor), 1998. Hukum dan Kekuasaan, FH UII, Yogyakarta.

Departemen Kesehatan Republik Indonesia. 2009, Pedoman Pelaksanaan Jaminan Kesehatan Masyarakat (Jamkesmas). Penerbit Depkes RI. Jakarta. 
Direktorat Jendral Bina Kesehatann Masyarakat.2009. Petunjuk Teknis Jaminan Kesehatan Masyarakat Puskesmas dan Jaringannya.

Fred Ameln, 1999. Kapita Selekta Hukum Kedokteran. Grafikatama Jaya. Jakarta.

Freddy Tengker, 2007. Hak Pasien. CV. Mandar Maju. Bandung.

Fauzan dan Heru Prasetyo,2006. Teori Keadilan,: Pustaka Pelajar,Yogyakarta

Hendrik. 2010. Etika dan Hukum Kesehatan. Penerbit buku kedokteran EGC. Jakarta.

Hadari Nawawi, 1994. Pengawasan Melekat di Lingkungan Aparatur Pemerintah. Penerbit Erlangga. Jakarta.

J.J Oostenbrink, A. Hamid S. Attamimi dalam Ridwan, HR. 2003. Hukum Administrasi Negara. UII Perss. Yogyakarta.

John Rawls,1973. A Theory of Justice, London: Oxford University press, yang sudah diterjemahkan dalam bahasa Indonesia oleh Uzair.

Johnny Ibrahim. 2011. Teori dan Metodologi Penlitian Hukum Normatif. Penerbit Bayu Media Publishing, Malang.

Jhon Salindeho, 1998. Tata Laksana Dalam Manajemen, Sinar Grafika, Jakarta.

Kartono Muhammad dkk. 1999. Rumah Sakit Antara Komersialisasi Dan Etika. Grafindo, Jakarta.

Miriam Budiardjo. 1982. Dasar-dasar Ilmu Politik. Gramedia. Jakarta.

M. Solly Lubis, 1989. Ilmu Negara, Mandar Maju, Bandung.

M.Manullang, 1995. Dasar-Dasar Manajemen, Ghalia Indonesia, Jakarta.

Muhammad Djafar Saidi, 2008. Perlindungan Hukum Wajib Pajak dalam Penyelesaian Sengketa Pajak. Raja Grafindo Persada, Jakarta.

Philipus M. Hadjon, 1987. Perlindungan Hukum Bagi Rakyat di Indonesia. PT Bina Ilmu, Surabaya.

Prayudi, 1981. Hukum Administrasi Negara, Ghalia Indonesia, Jakarta.

Paulus E. Lotulung, 1993. Beberapa Sistem Tentang Kontrol Segi Hukum Terhadap Pemerintah. PT.Citra Aditya Bakti, Bandung.

Peter Mahmud Marzuki, 2008 . Penelitin Hukum, Cet, keempat. Penerbit. Prenada Media Group . Jakarta.

Pipin Syarifin dan Dedah Junaedah, 2005. Hukum Pemerintahan Daerah, Cet. I. Pustaka Bani Quraisy. Bandung.

Ridwan HR, 2006. Hukum Administrasi Negara. Pt. Raja Grafindo Persada. Jakarta.

Rosemary McMahon..[et al]; alih bahasa, Poppy Kumala; editor, Brahm U. Pendit,1999. Manajemen Pelayanan Kesehatan Primer, Penerbit Buku Kedokteran EGC. Jakarta.

Solly Lubis, 1992. Asas-asas Hukum Tata Negara, Alumni. Bandung.

Suganda Wirnanngapati dkk, 1992. Sejarah Nasional Indonesia dan Dunia, PT. Galaxy Puspa Mega, Jakarta.

Sudargo Gautama, 1973. Pengertian Tentang Negara Hukum. Alumni .Bandung.

Soerjaono Soekanto,1983. Penegkan Hukum. Bina Cipta. Bandung .

Sri Soemantri Martosoewignjo, 1995. Sistem-sistem Pemerintahan Negara-negara ASEAN. Tarsito. Bandung.

Saiful Anwar.2004, Sendi-Sendi Hukum Administrasi Negara, Glora Madani Press. Jakarta

Soehino, 1980. Ilmu Negara, Yogyakarta: Liberty.

Shidarta , 2004. Hukum Perlindungan Konsumen Indonesia. Grafindo. Jakarta.

Sujanto,1986. Beberapa Pengertian di Bidang Pengawasan, Ghalia Indonesia, Jakarta

Tahir Azhary, 1995. Negara Hukum Indonesia, Analisis Yuridis Normtif Tentang unsur-unsurnya. Jakarta, UI Perss.

Theo Huijbers, 1995. Filsafat Hukum dalam lintasan sejarah, cet VIII, Yogyakarta: Kanisius, Yogyakarta.

Theo Huijbers, 1988. Filsafat Hukum dalam Lintasan Sejarah, Cet. Kelima, Yogyakarta: Penerbit Kanisius.

Uton Muchtar Rafei, 2007. "Health Politics" Menjangkau Yang Tak Terjangkau. Diterbitkan oleh. Health \& Hospital Indonesia, cet. I, Jakarta.

UUD 1945 hasil amandemen, perubahan keempat disahkan 10 Agustus 2002. Jakarta: Sinar Grafika, 2002.

Veronica komalawati. 1989. Hukum dan Etika Dalam Praktek Kedokteran. Pustaka Sinar Harapan .Jakarta.

Wiku Adisasmito, M.Sc, Ph.D. 2008 Analisis Perjalanan Rancangan Undang-Undang Kesehatan (RUU Kesehatan) Fakultas Kesehatan Masyarakat Universitas Indonesia.

\section{Journal From Media Electronics:}

http://gagasanhukum.wordpress.com/2010/10/11/hak-orang-miskin-memperoleh-pelayanan-kesehatan-bagan-i/ "Hak Orang Miskin Memperoleh Pelayanan Kesehatan" (Sumber: www.p3b.bappenas.go.id/.../(02)Prinsip-prinsip\%20Good\%20Governance) (http://www.tribun-timur.com/view.php?id=78351\&jenis=Opini)

(Rabu, 25 Februari 2009 Berdikari Online, Makassar. http://www.berdikari.org )

http://www.tribuntimur.com/view.php?id=78351\&jenis=Opini)

http://www.bps.go.id/index.php?news=821 “ Penjelasan Data Kemiskinan”BPS-RI. Jakarta, 27 Januari 2011

Berita Resmi Statistik Provinsi Sulawesi Selatan No. 36/07/73/Th. V, 1 Juli 2011. Hal.4 http://www.bps.go.id/index.php?news=821 “ Penjelasan Data Kemiskinan”BPS-RI. Jakarta, 27 Januari $2011^{1}$

http://www.depsos.go.id/database/digitalisasi2009/files/2002-penduduk fakir miskin/Pendudduk FM 2002.pdf

Website Inspektorat Jenderal Kementerian Dalam Negeri "Pengertian Pengawasan” 
The IISTE is a pioneer in the Open-Access hosting service and academic event management. The aim of the firm is Accelerating Global Knowledge Sharing.

More information about the firm can be found on the homepage:

http://www.iiste.org

\section{CALL FOR JOURNAL PAPERS}

There are more than 30 peer-reviewed academic journals hosted under the hosting platform.

Prospective authors of journals can find the submission instruction on the following page: http://www.iiste.org/journals/ All the journals articles are available online to the readers all over the world without financial, legal, or technical barriers other than those inseparable from gaining access to the internet itself. Paper version of the journals is also available upon request of readers and authors.

\section{MORE RESOURCES}

Book publication information: http://www.iiste.org/book/

Academic conference: http://www.iiste.org/conference/upcoming-conferences-call-for-paper/

\section{IISTE Knowledge Sharing Partners}

EBSCO, Index Copernicus, Ulrich's Periodicals Directory, JournalTOCS, PKP Open Archives Harvester, Bielefeld Academic Search Engine, Elektronische Zeitschriftenbibliothek EZB, Open J-Gate, OCLC WorldCat, Universe Digtial Library, NewJour, Google Scholar

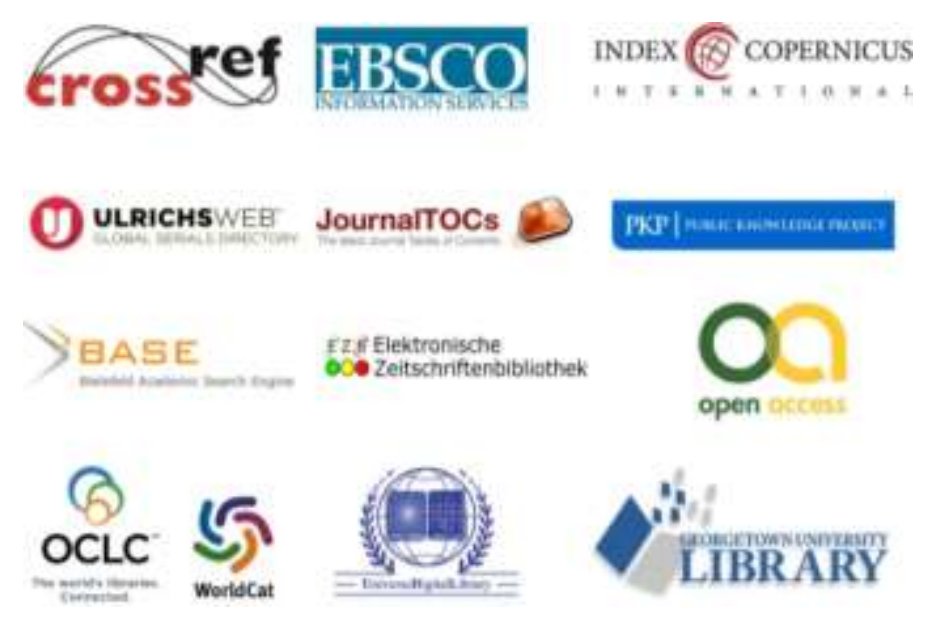

